\title{
Grow Moringa (Moringa oleifera), the miracle tree on the earth
}

\begin{abstract}
Moringa (Moringa oleifera) is commonly known as 'drumstick tree' or 'horseradish tree' is native to India, grows in the tropical and subtropical regions of the world. With its high nutritive values, every part of the tree is suitable for nutritional as well as commercial purposes. The leaves are rich in minerals, vitamins and other essential phytochemicals. Leaf extract is used to treat malnutrition, augment breast milk in lactating mothers. It is used as potential antioxidant, anticancer, anti-inflammatory, anti diabetic and antimicrobial agent. Moringa Vallabh 1 flowers twice in a year i.e., July-August and October- November while the Local flowers once in year i.e. October and November. The peak flowering takes place during August- September and December-January in Vallabha 1 while December-January only in Local. Further, fruit harvesting is done during November- December and February March, respectively in Vallabh 1 and February March in Local. The fruit length was recorded $82.7-83.1 \mathrm{~cm}$ during October-November harvesting where it was noted 75.1-75.2cm during January -February harvesting from 2013 to 2016 in Vallabh 1 while it was noted $56.1-57.3 \mathrm{~cm}$ in Local cultivar.. The fruit yield was increased from $97.87 \mathrm{~kg}$ to $204.13 \mathrm{~kg}$ from 2013 to 2016 during October-November where as it was noted 75.36 to $126.80 \mathrm{~kg}$ during January- February during the same year in Vallabh 1 while it was noted 27.15 to $71.48 \mathrm{kgper}$ tree in Local. In this way it is concluded that Moring Vallabh 1 is found to the best among the existing strains which bears fruit twice in a year.
\end{abstract}

Volume 2 Issue 4 - 2018

\author{
Yogesh Prasad Rajbhar, Govind Rajbhar, \\ Rawat PL, Shardulya Shukla, Manoj Kumar \\ Department of Horticulture, Sardar Vallabhbhai Patel University \\ of Agriculture \& Technology, India
}

Correspondence: Yogesh Prasad Rajbhar, Department of Horticulture, Sardar Vallabhbhai Patel University of Agriculture \& Technology, Meerut-250I 10 (U.P), India, Email rajbhar.yogesh@gmail.com

Received: December 26, 2017 | Published: July 25, 2018

\section{Introduction}

Moringa oleifera belongs to the family of Moringaceae is an embodiment of nutritional treasure due to many essential phytochemicals present in its leaves, pods and seeds. It provides 7 times more vitamin $\mathrm{C}$ than oranges, 9 times more protein than yoghurt, 10 times more vitamin A than carrots, 15times more potassium than bananas, 17 times more calcium than milk and 25times more iron than spinach. ${ }^{1}$ It is a sustainable remedy for malnutrition. Senegal and Benin of African countries treat their children with moringa who are deprived of breast milk. ${ }^{2}$ To augment milk production, the lactogogue, made of phytosterols, acts as a precursor for hormones required for reproductive growth and are generally prescribed to lactating mothers. It is rich in stigmasterol, sitosterol and kampesterol the phytosterols which increase the estrogen production, resulting stimulates the proliferation of the mammary gland ducts to produce milk. ${ }^{3}$ About 6 spoonfuls of moringa leaf powder can meet a pregnant woman's daily iron and calcium requirement.

\section{Soil and climate}

It can be grown in tropical and subtropical regions of the world with a temperature ranging from $25-35^{\circ} \mathrm{C}$. It grows well in sandy or loamy soil with pH6.5-7.5 and a rainfall of $250-300 \mathrm{~cm} .{ }^{4}$ Direct seeding method is generally preferred as it germinates profusely. The seeds are sown in $2 \mathrm{~cm}$ deep in well prepared nursery which germinate within 5-12days. $30 \mathrm{~cm}$ high seedlings are ready for transplanting in the open field at $5 \times 5 \mathrm{~m}$ apart. It can also be propagated through cutting having $1 \mathrm{~m}$ length and $4-5 \mathrm{~cm}$ in diameter, but due to shallow root system these plants tend to be sensitive to drought and winds.

\section{Nutritive value}

Moringa oleifera is a storehouse of nutrients. The leaves are rich in calcium, potassium, iron, zinc, magnesium and copper. ${ }^{2}$ Vitamins like vitamin $\mathrm{A}$, vitamin $\mathrm{B}$ complex as folic acid, pyridoxine and nicotinic acid, vitamin $\mathrm{C}, \mathrm{D}$ and $\mathrm{E}$ are present in huge amount. ${ }^{5}$ Tannins, sterols, terpenoids, flavonoids, saponins, anthraquinones, alkaloids; the phytochemicals and reducing sugar along with anti-cancerous agents like glucosinolates, isothiocyanates, glycoside compounds and glycerol-1-9-octadecanoate are present abundantly. ${ }^{6}$ The leaves can be used in the diet of the obese as they have a low calorific value. To treat digestive problems and thwart the colon cancer; the pods are very valuable due to their fibrous natyre. ${ }^{7}$ The immature pods contain 46.78per cent fiber and 20.66per cent protein. The pods, leaves and flowers contain 30, 44 and 31 per cent amino acids, respectively. The immature pods and flowers showed similar amounts of palmitic, linolenic, linoleic and oleic acids. ${ }^{8} 227 \mathrm{~g}$ of Moringa leaves can provide $1000 \mathrm{mg}$ and Moringa powder can provide more than $4000 \mathrm{mg}$ while the same amount of milk can provide $300-400 \mathrm{mg}$ calcium only. Moringa powder can be used as a substitute of iron tablets for treatment of anemia. For proper growth of sperm cells and for the synthesis of DNA and RNA; intake of zinc is essential in a good diet. Moringa leaves contain $25.5-31.03 \mathrm{mg}$ of zinc per kg mass, which is the daily requirement of zinc in the diet Table $1 .{ }^{9}$

\section{Processing of Moringa leaves as well as fruits}

The phytochemicals were higher in raw seed flour and amino acid content was at its peak in fermented and germinated seed flour due to the biochemical activities during germination and microbial activity during fermentation. ${ }^{12,13}$ The boiling was the most effective of all the techniques as it reduced the cyanide, oxalate and phytate contents, more significantly than the other two methods as simmering and blanching. The bioavailability of certain nutrients; processing can be done for maximum utilization of required nutrients from the seeds and leaves as the presence of phytate and other anti-nutrients can reduce 
them. ${ }^{14,15}$ Yang et al., ${ }^{16}$ reported that boiling enhanced the availability of iron and antioxidant content. So, the processed moringa seed flour can be used to treat the persons suffering of malnutrition. Kiranawati et al. ${ }^{17}$ designed sautéing, steaming and boiling of moringa noodles cooking. These noodles were tested on rat's mammary glands. The sautéed noodles had a better effect on the mammary glands of rats and improved milk production. The oil used was rich in sterols which effect on sautéing noodles; improved lactogogum values. 20per cent Moringa oleifera have also been incorporated into cocoa powder for fortification in the chocolate preparation.

Table I The nutrient compositions ${ }^{\mathrm{a}}$ of leaves, leaf powder, seeds and pods

\begin{tabular}{|c|c|c|c|c|c|}
\hline Nutrients & Fresh leaves & Dry leaves & Leaf powder & Seed & Pods \\
\hline Calories (cal) & 92 & 329 & 205 & - & 26 \\
\hline Protein (g) & 6.7 & 29.4 & 27.1 & $35.97 \pm 0.19$ & 2.5 \\
\hline Fat $(g)$ & 1.7 & 5.2 & 2.3 & $38.67 \pm 0.03$ & 0.1 \\
\hline Carbohydrate (g) & 12.5 & 41.2 & 38.2 & $8.67 \pm 0.12$ & 3.7 \\
\hline Fibre $(g)$ & 0.9 & 12.5 & 19.2 & $2.87 \pm 0.03$ & 4.8 \\
\hline Vitamin BI (mg) & 0.06 & 2.02 & 2.64 & 0.05 & 0.05 \\
\hline Vitamin B2 (mg) & 0.05 & 21.3 & 20.5 & 0.06 & 0.07 \\
\hline Vitamin B3 (mg) & 0.8 & 7.6 & 8.2 & 0.2 & 0.2 \\
\hline Vitamin C (mg) & 220 & 15.8 & 17.3 & $4.5 \pm 0.17$ & 120 \\
\hline Vitamin E (mg) & 448 & 10.8 & 113 & $75 I .67 \pm 4.4 I$ & - \\
\hline Calcium (mg) & 440 & 2185 & 2003 & 45 & 30 \\
\hline Magnesium (mg) & 42 & 448 & 368 & $635 \pm 8.66$ & 24 \\
\hline Phosphorus (mg) & 70 & 252 & 204 & 75 & 110 \\
\hline Potassium (mg) & 259 & 1236 & 1324 & - & 259 \\
\hline Copper (mg) & 0.07 & 0.49 & 0.57 & $5.20 \pm 0.15$ & 3.1 \\
\hline Iron (mg) & 0.85 & 25.6 & 28.2 & - & 5.3 \\
\hline Sulphur (mg) & - & - & 870 & 0.05 & 137 \\
\hline
\end{tabular}

All values are in $100 \mathrm{~g}$ per plant material..$^{9-11}$

\section{Method of preservation}

Moringa can be preserved without any loss of nutrients for a long time. Dried or freezed leaves can be stored. Yang et al., ${ }^{16}$ showed that a low temperature oven used to dehydrate the leaves retained more nutrients except vitamin $\mathrm{C}$ than freeze-dried leaves. Therefore, sun drying can be done easily under household appliance to maintain sustainable supply of nutrients in the leaves. The shelf life of moringa can be improved during preservation by dehydration without change in nutritional value. An extra dose of moringa may cause high accumulation of iron which can cause gastrointestinal distress and hemochromatosis problems. Therefore, a daily dose of $70 \mathrm{~g}$ of moringa is suggested to be good which prevents over accumulation of nutrients. ${ }^{18}$

\section{Medicinal properties}

Moringa is really referred as panacea and can be used to cure numerous diseases. It has long been used in herbal medicine by Indians and Africans. The presence of phytochemicals makes it a good medicinal agent.

\section{Anti-diabetic properties}

Moringa has been found to cure both Types of diabetes. The patients suffer from non-production of insulin is known as Type 1 diabetes, which is a hormone that maintains the blood glucose level at the required value. Type 2 diabetes is associated with insulin resistance. This might also be due to Beta cell dysfunction, which fails to sense glucose levels, therefore reduces the signaling to insulin, resulting in high blood glucose levels. ${ }^{19}$ Moringa acts as an anti-diabetic agent as the aqueous extracts of $M$. oleifera can cure streptozotocin-induced Type 1 diabetes and also insulin resistant Type 2 diabetes. Since beta cells have low number of antioxidants, this in turn causes apoptosis of the beta cells. ${ }^{20,21}$ This reduces insulin secretion leading to hyperglycemia and in turn diabetes mellitus Type-2. The quercitin and phenolics flavonoids have been attributed as antioxidants that bring about a scavenging effect on ROS. It can be hypothesized that the flavonoids in Moringa scavenge the ROS released from mitochondria, thereby protecting the beta cells and in turn keeping hyperglycemia under control..$^{22,23}$ The high glucose in blood enters glycolysis in the mitochondria of beta cells and forms reactive oxygen species. This then causes apoptosis of beta cells which in turn leads to decreased insulin secretion, hyperglycemia and ultimately Type- 2 diabetes. However, the cell apoptosis of beta cells can be averted by the use of moringa. It has antioxidants which combine with the reactive oxygen species

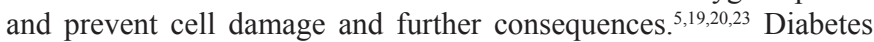
may cause several complications such as retinopathy, nephropathy and atherosclerosis, etc. So, moringa can be used to prevent such ailments. Where there is hyperglycemia, the blood glucose reacts with proteins and causes advanced glycated end products (AGEs). These AGEs bind to RAGE which gets expressed on the surface of immune 
cells. This interaction leads to increased transcription of cytokines like interleukin- 6 and interferons. At the same time, the cell adhesion molecules are expressed on the surface endothelium of arteries. ${ }^{24}$ This facilitates transendothelial migration which causes inflammation in the arteries and leads to atherosclerosis. Moringa is used as an antiatherosclerotic agent. ${ }^{25}$ The anti-atherogenic nature can be accounted for by the antioxidant properties of moringa.

\section{Anticancer properties}

Moringa can be used as an anticancer agent as it is natural, reliable and safe, at established concentrations. It can be used as an antineoproliferative agent, thereby inhibiting the growth of cancer cells. Soluble and solvent extracts of leaves have been proven effective as anticancer agents. Furthermore, research papers suggest that the anti-proliferative effect of cancer may be due to its ability to induce reactive oxygen species in the cancer cells. The reactive oxygen species induced in the cells leads to apoptosis. This is further proved by the up regulation of caspase 3 and caspase 9 , which are part of the apoptotic pathway. ${ }^{26-28}$ Moreover, the ROS production by moringa is specific and targets only cancer cells, making it an ideal anticancer agent. Tiloke et al., ${ }^{26}$ also showed that the extracts increased the expression of glutathione-S-transferase, which inhibits the express of antioxidants. Anticancer agents targeting cancer using ROS induction are common, but these substances should also be able to attack the antioxidant enzymes. ${ }^{29}$ Moringa leaf extracts have antioxidants and anticancer agents which induce ROS. The compounds of the leaves that are held responsible for the anticancer activities are glucosinolates, niazimicin and benzyl isothiocyanates..$^{30}$ Benzyl isothiocyanate has been shown to be linked with cancer. BITC causes intracellular ROS, which leads to cell death. This could be one of the reasons for moringa to be a good anticancer agent. ${ }^{31-33}$

\section{Other diseases}

Moringa can be used as an important neuroprotectant. Cerebral ischemia is caused due to obstruction of blood flow to the brain. This leads to reperfusion and lipid peroxidation, which in turn results in reactive oxygen species. Moringa with its antioxidants can reduce the reactive oxygen species, thereby protecting the brain. ${ }^{34,35}$ It is used to treat dementia, as it has been shown to be a promoter of spatial memory. The leaf extracts have shown to decrease the acetylcholine esterase activity, thereby improving cholinergic function and memory. ${ }^{36}$ Adeyemi et al., ${ }^{37}$ showed that moringa in diet can increase protein content and decrease levels of urea and creatinine in blood, preventing renal dysfunction. Moringa decreased acidity in gastric ulcers by a percentage of 86.15 and 85.13 at doses of $500 \mathrm{mg}$ and $350 \mathrm{mg}$, respectively and therefore can be used as an antiulcer agent. ${ }^{38}$ It is prescribed for patients suffering from AIDS. It is suggested to be included in the diet, with the view of boosting the immune system of HIV positive individuals. The hydro-alcoholic extract of moringa flowers reduced the levels of rheumatoid factor, TNF-alpha and IL-1 in arthritic rats. So, moringa can be an important therapy for arthritis. ${ }^{39} \mathrm{It}$ has been proven as a good antimicrobial agent. ${ }^{40}$ Viera et al. ${ }^{41}$ has shown that the extracts of Moringa oleifera can act against bacteria like Bacillus subtilis, Staphylococcus aureus and Vibrio cholera. The antibacterial effects of the seeds were accounted for by the presence of pterygospermin, moringine and benzyl isothiocyanates Table $2{ }^{42}$

Table 2 Nutritional compositions and medicinal uses of different parts of Moringa

\begin{tabular}{|c|c|c|c|}
\hline $\begin{array}{l}\text { Part of } \\
\text { tree }\end{array}$ & Medicinal uses & Nutritive properties & Suggestion \\
\hline Leaves & $\begin{array}{l}\text { Moringa leaves treat asthma, } \\
\text { hyperglycemia, Dyslipidemia, flu, heart } \\
\text { burn, syphilis, malaria, pneumonia, diarrhea, } \\
\text { headaches, scurvy, skin diseases, bronchitis, } \\
\text { eye and ear infections. Also reduces, blood } \\
\text { pressure and cholesterol and acts as an } \\
\text { anticancer, antimicrobial, Antioxidant, anti } \\
\text { diabetic and anti-atherosclerotic agents, } \\
\text { neuroprotectant }\end{array}$ & $\begin{array}{l}\text { Moringa leaves contain fiber, fat proteins and minerals } \\
\text { like } \mathrm{Ca}, \mathrm{Mg}, \mathrm{P}, \mathrm{K}, \mathrm{Cu}, \mathrm{Fe} \text {, and S;Vitamin-A ( }{ }_{\beta} \text {-carotene), } \\
\text { vitamin B-choline, vitamin BI-thiamine, riboflavin, } \\
\text { nicotinic acid and ascorbic acid are present.Various } \\
\text { amino acids like Arg, His, Lys, Trp, Phe, Thr, Leu, Met, } \\
\text { lle,Val are present. Phytochemicals like tannins, } \\
\text { sterols, saponins, trepenoids, phenolics, alkaloids and } \\
\text { flavonoids like quercetin, isoquercitin, kaemfericitin, } \\
\text { isothiocyanates and glycoside compounds are present }\end{array}$ & $\begin{array}{l}\text { Presence of flavonoids provides leaves } \\
\text { the anti diabetic and antioxidant } \\
\text { properties. The isothiocyanates are } \\
\text { anticancer agents. Flavonoids like } \\
\text { quercetin and others are known for } \\
\text { anti-proliferative, anticancer agent. } \\
\text { Presence of minerals and vitamins } \\
\text { help in boosting the immune system } \\
\text { and cure a myriad of diseases. } \text {, }^{1,9,11,12,26}\end{array}$ \\
\hline Seeds & $\begin{array}{l}\text { Help in treating hyperthyroidism, } \\
\text { Chrohn's disease, antiherpes-simplex virus } \\
\text { arthritis, rheumatism, gout, cramp, epilepsy } \\
\text { and sexually transmitted diseases, can act } \\
\text { as antimicrobial and anti-inflammatory } \\
\text { agents }\end{array}$ & $\begin{array}{l}\text { Contains oleic acid (Ben oil), antibiotic called } \\
\text { pterygospermin, and fatty acids like Linoleic acid, } \\
\text { linolenic acid, behenic acid, Phytochemicals like tannins, } \\
\text { saponin, phenolics, phytate, flavanoids, terpenoids and } \\
\text { lectins. Apart from these, fats, fiber, proteins, minerals, } \\
\text { vitamins like A, B, C and amino acids }\end{array}$ & $\begin{array}{l}\text { Flavonoids have anti-inflammatory } \\
\text { property. The antibiotic } \\
\text { pterygospermin is responsible for } \\
\text { antimicrobial properties. The other } \\
\text { phyto-chemicals help in treating } \\
\text { various diseases. }^{\mid-4,43,44}\end{array}$ \\
\hline Root Bark & $\begin{array}{l}\text { Root bark acts as a cardiac stimulant, anti- } \\
\text { ulcer and anti-inflammatory agent }\end{array}$ & $\begin{array}{l}\text { Alkaloids like morphine, moriginine, minerals like } \\
\text { calcium, magnesium and sodium }\end{array}$ & $\begin{array}{l}\text { The alkaloid helps the bark to be } \\
\text { antiulcer, a cardiac stimulant and helps } \\
\text { to relax the muscles. }{ }^{38,45}\end{array}$ \\
\hline Flower & $\begin{array}{l}\text { Moringa flowers act as } \\
\text { hypocholesterolemic, anti-arthritic agents } \\
\text { can cure urinary problems and cold }\end{array}$ & $\begin{array}{l}\text { It contains calcium and potassium and amino acids. } \\
\text { They also contain nectar }\end{array}$ & $\begin{array}{l}\text { The presence of nectar makes them } \\
\text { viable for use by beekeepers. }{ }^{9,34}\end{array}$ \\
\hline Pods & $\begin{array}{l}\text { Moringa pods treat diarrhea, liver and } \\
\text { spleen problems, and joint pain }\end{array}$ & $\begin{array}{l}\text { Rich in fiber, lipids, non-structural carbohydrates, } \\
\text { protein and ash. Fatty acids like oleic acid, linoleic acid, } \\
\text { palmitic acid and linolenic acid are also present }\end{array}$ & $\begin{array}{l}\text { The presence of PUFA in the pods } \\
\text { can be used in the diet of obese. }\end{array}$ \\
\hline
\end{tabular}




\section{Commercial value}

Moringa seeds are used to extract oil called the Ben oil. It is rich in oleic acid, tocopherols and sterols. It can also withstand oxidative rancidity. The oil can be used in cooking as a substitute for olive oil, as perfumes and also for lubrication. ${ }^{31,46}$ The pods can absorb organic pollutants and pesticides. Its seed also has great coagulant properties and can precipitate organics and mineral particulates. ${ }^{1,47}$ Chemical coagulants such as aluminum sulfate and ferric sulfate or polymers remove suspended particles in waste water by neutralizing the electrical charges of particles in the water to form flocs making particles filterable. Moringa seed is a natural coagulant, containing a cationic protein that can clarify turbid water. This property is attracting much research as other coagulants such as alum, activated carbon and ferric chloride are expensive and rare. ${ }^{48}$ Suhartini et al. ${ }^{49}$ developed a two-stage clarifier for the treatment of tapioca starch waste water by placing coconut fiber followed by a layer of sand media mixed with powdered Moringa oleifera, this lead to improvement on physical and chemical characteristics, stabilizing $\mathrm{pH}$ value. Moringa seed extract has the ability to eliminate heavy metals as lead, copper, cadmium, chromium and arsenic from water. ${ }^{39}$ Moringa oleifera functionalized with magnetic nanoparticles such as iron oxide were found beneficial in surface water treatment by lowering settling time. ${ }^{50}$ Seed extracts have antimicrobial properties that inhibit bacterial growth, which implies preventing waterborne diseases. These properties of Moringa oleifera seeds have wide applicability in curing diseases and can enhance the life quality in rural communities as it is found abundantly.

Its seed can be used in cosmetics and good sources of biodiesel while the seedcake, can be used as manure. Its flower is used to make tea with hypocholesterolemic properties. Its flower is rich source of nectar for honeybee. The root bark has medicinal values and is used for dyspepsia, eye diseases and heart complaints. ${ }^{51}$ Its tap root is used as spice. The gum from the tree can be used in calicoprinting. The gum and roots also have antibacterial, antifungal and anti-inflammatory properties..$^{52}$ The growth hormone from the leaves, called Zeatin is an excellent compound for foliar application and can enhance the yield by 25-30per cent. ${ }^{53}$ Incorporation and fortification of moringa can be significantly overcome the nutrient deficiencies and malnutrition. Aluko et al., ${ }^{54}$ evaluated that 92.5 per cent maize and 7.5 per cent moringa seed flour combination was well accepted due to its crispness, aroma, taste and colour. Cereal gruels have also been fortified by moringa leaves in order to improve the protein content and energy. Owusu et al., ${ }^{55}$ used moringa as a fortificant and produced cream and butter crackers with moringa and Ipomoea batatas as fortificants, for adding additional nutrients to snacks. M. oleifera leaves can be incorporated in the diet of hens and layers thereby providing excellent protein source, substituting other expensive ingredients such as soybean meal and ground nut cake. ${ }^{56,57}$ In light of several studies, it is suggested that such addition can be done to prepare varieties of snacks.

Generally snacks are made up of corn meal; so, a little addition of moringa to maize flour can add nutritive value to it in the form of protein, energy and minerals. Moringa Vallabh 1 and Local sticks of $1.0 \mathrm{~m}$ length and $20 \mathrm{~cm}$ girth were planted in the boundary of Medicine Fruits Block of Horticultural Research Centre at Sardar Vallabhbhai Patel University of Agriculture \& Technology, Meerut (U.P.) during February 2013. Their vegetative characters, flowering and fruit yield were presented in the Table 3. At this region Moringa Vallabh 1 flowers twice in a year i,e, July-August and October- November while the Local flowers once in year i.e. October and November. The peak flowering takes place during August- September and DecemberJanuary in Vallabha 1 while December-January only in Local. Further, fruit harvesting is done during November- December and February March, respectively in Vallabh 1 and February March in Local. The fruit length was recorded $82.7-83.1 \mathrm{~cm}$ during October-November harvesting where it was noted $75.1-75.2 \mathrm{~cm}$ during January -February harvesting from 2013 to 2016 in Vallavh 1 while it was noted 56.1$57.3 \mathrm{~cm}$ in Local cultivar.. The fruit yield was increased from $97.87 \mathrm{~kg}$ to $204.13 \mathrm{~kg}$ from 2013 to 2016 during October-November where as it was noted 75.36 to $126.80 \mathrm{~kg}$ during January- February during the same year in Vallabh 1 while it was noted 27.15 to $71.48 \mathrm{kgper}$ tree in Local. In this way it is concluded that Moring Vallabh 1is found to the best among the existing strains which bears fruit twice in a year(Figures 1-3).

Table 3 Vegetative characters, flowering and fruit yield of Moringa Vallabh I and local

\begin{tabular}{|c|c|c|c|c|c|c|c|c|c|}
\hline \multirow{2}{*}{ Character } & \multicolumn{3}{|l|}{2014} & \multicolumn{3}{|l|}{2015} & \multicolumn{3}{|l|}{2016} \\
\hline & \multicolumn{2}{|l|}{ Vallabh I } & Local & \multicolumn{2}{|l|}{ Vallabh I } & Local & \multicolumn{2}{|l|}{ Vallabh I } & Local \\
\hline Tree height (m) & 2.35 & & 2.57 & 3.95 & & 4.21 & 4.8 & & 5.67 \\
\hline Trunk girth $(\mathrm{cm})$ & 21.5 & & 25.5 & 36.5 & & 41.5 & 45.8 & & 57.4 \\
\hline Plant spread (E-W) (m) & 1.85 & & 1.97 & 2.95 & & 3.23 & 3.5 & & 3.74 \\
\hline Plant spread (N-S) (m) & 1.75 & & 1.88 & 2.85 & & 3.28 & 3.45 & & 3.67 \\
\hline Leaf length (cm) & 92.5 & & 86.4 & 93.4 & & 87.6 & 93.5 & & 87.1 \\
\hline Flower initiation & Jul-Aug & Oct-Nov & Oct-Nov & Jul-Aug & Oct-Nov & Oct-Nov & Jul-Aug & Oct-Nov & Oct-Nov \\
\hline Peak flowering & Aug-Sep & Dec-Jan & Dec-Jan & Aug-Sep & Dec-Jan & Dec-Jan & Aug-Sep & Dec-Jan & Dec-Jan \\
\hline Fruit harvesting & Oct-Nov & Jan-Feb & Jan-Feb & Oct-Nov & Jan-Feb & Jan-Feb & Oct-Nov & Jan-Feb & Jan-Feb \\
\hline Fruits / panicle & 28.5 & 22.4 & 14.4 & 32.3 & 24.2 & 24.2 & $37 / 8$ & 26.2 & 26.2 \\
\hline Fruit length $(\mathrm{cm})$ & 82.7 & 75.1 & 56.1 & 83.2 & 75.4 & 56.5 & 83.1 & 75.2 & 57.3 \\
\hline Fruit girth $(\mathrm{cm})$ & 7.2 & 6.5 & 5.8 & 7.2 & 6.4 & 5.3 & 7.2 & 6.3 & 6 \\
\hline Fruit weight (g) & 130.5 & 125.6 & 87.6 & $131.5 \mathrm{~g}$ & 126.4 & 86.4 & 131.7 & 126.8 & 84.8 \\
\hline Number of fruits/tree & 750 & 600 & 310 & 1150 & 970 & 465 & 1550 & 1000 & 843 \\
\hline Fruit yield/tree $(\mathrm{kg})$ & 97.87 & 75.36 & 27.15 & 151.22 & 122.6 & 40.17 & 204.13 & 126.8 & 71.48 \\
\hline
\end{tabular}




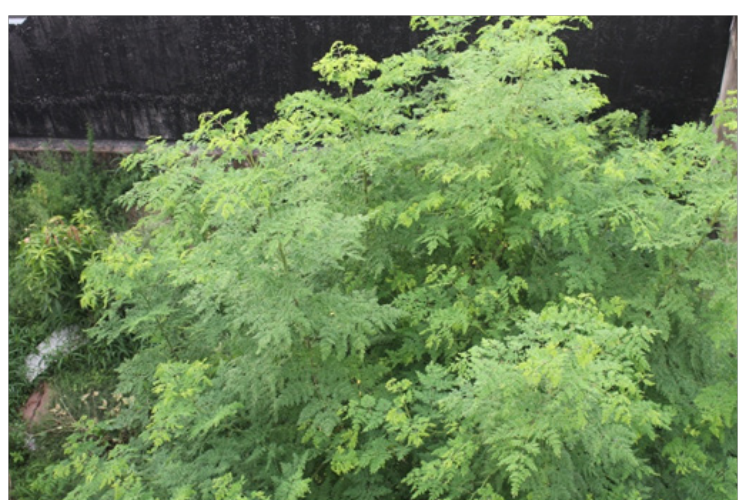

Figure I Moringa Vallabh I tree.

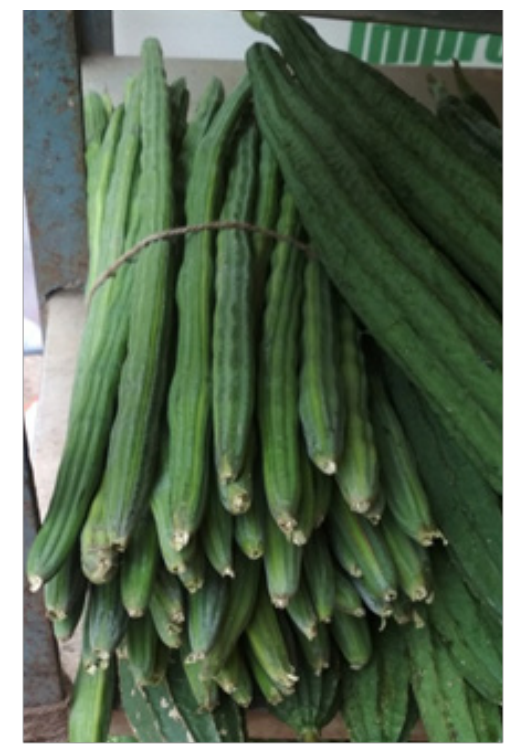

Figure 2 Moringa Vallabh I fruits.

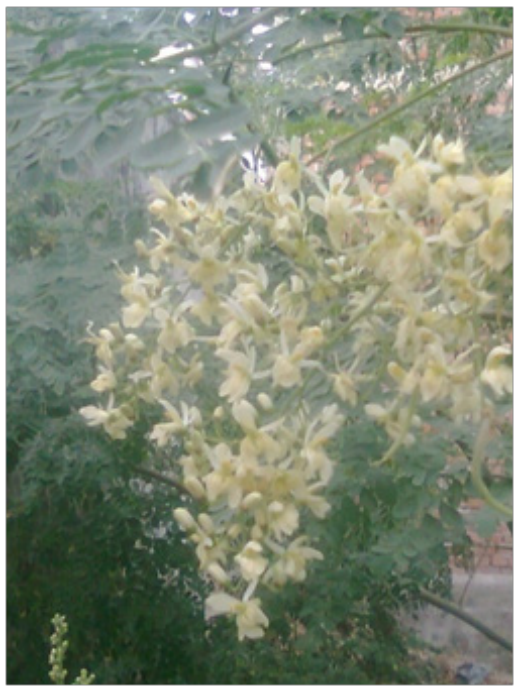

Figure 3 Moringa Vallabh I in full bloom.

\section{Conclusion and future prospects}

There is need of research on M. oleifera to gain its importance in India. It is essential that the nutrients of this wonder tree are exploited for different purposes. It has great anti-diabetic and anti-cancer properties. Moringa Vallabh 1 is found to the best among the existing strains which bears fruit twice in a year.

\section{Acknowledgements}

None.

\section{Conflict of interest}

Author declares that there is no conflict of interest.

\section{References}

1. Rockwood JL, Anderson BG, Casamatta DA. Potential uses of Moringa oleifera and an examination of antibiotic efficacy conferred by $M$. oleifera seed and leaf extracts using crude extraction techniques available to underserved indigenous populations. Int $J$ Phytothearpy Res. 2013;3(2):61-71.

2. Kasolo JN, Bimenya GS, Ojok L, et al. Phytochemicals and uses of Moringa oleifera leaves in Ugandan rural communities. $J$ Med Plants Res. 2010;4(9):753-757.

3. Mutiara TK, Harijono, Teti Estiasih, et al. Effect lactagogue moringa leaves Moringa oleifera Lam powder in rats. J Basic Appl Sci Res. 2013;3(4):430-434

4. Thurber MD, Fahey JW. Adoption of Moringa oleifera to combat undernutrition viewed through the lens of the diffusion of innovations theory. Ecol Food Nutr. 2010;48(3):212-225.

5. Mbikay M. Therapeutic potential of Moringa oleifera leaves in chronic hyperglycemia and dyslipidemia: a review. Front Pharmacol. 2012;3:24.

6. Berkovich L, Earon G, Ron I, et al. Moringa oleifera aqueous leaf extract down-regulates nuclear factor-kappaB and increases cytotoxic effect of chemotherapy in pancreatic cancer cells. BMC Complement Altern Med. 2013;13:212.

7. Oduro I, Ellis WO, Owusu D. Nutritional potential of two leafy vegetables: Moringa oleifera and Ipomoea batatasleaves. Sci Res Essays. 2008;3(2):57-60.

8. Sánchez Machado DI, Núñez Gastélum JA. Reyes Moreno C, et al. Nutritional quality of edible parts of Moringa oleifera. Food Anal Methods. 2010;3(3):175-180.

9. Barminas JT, Charles M, Emmanuel D. Mineral composition of nonconventional leafy vegetables. Plant Foods Hum. Nutr.1998;53(1):29-36.

10. Olagbemide PT, Alikwe PC. Proximate analysis and chemical composition of raw and defatted Moringa oleifera kernel. Adv Life Sci Technol. 2014;24:92-99.

11. Moringa Leaf Powder: A nutritional analysis of leaf powder.

12. Ijarotimi OS, Adeoti O, Ariyo O. Comparative study on nutrient composition, phytochemical, and functional characteristics of raw, germinated, and fermented Moringa oleifera seed flour. Food Sci Nutr. 2013;1(6):452-463.

13. Mishra SP, Singh P, Singh S. Processing of Moringa oleifera leaves for human consumption. Bull Environ Pharmacol Life Sci. 2012;2(1):2831. 
14. Sallau B, Mada SB, Ibrahim S. Effect of boiling, simmering and blanching on the antinutritional content of Moringa oleifera leaves. Int J Food Nutr Saf. 2012;2:1-6.

15. Kachik F, Mudlagiri BG, Gary RB, et al. Effects of food preparation on qualitative and quantitative distribution of major carotenoids constituents of tomatoes and several green vegetables. J Agric Food Chem. 1992;40(3):390-398.

16. Yang R, Chang L, Hsu J, et al. Nutritional and functional properties of moringa leaves from germplasm, to plant, to food, to health. Am Chem Soc. 2006;1-17.

17. Kiranawati TW, Nurjanah N. Improvement of noodles recipe for increasing breastmilk: design of the Moringa noodles. Am J Food Sci Technol. 2014;2(3):88-92.

18. Asiedu Gyekye IJ, Frimpong Manso S, Awortwe C, et al. Micro and macroelemental composition and safety evaluation of the nutraceutical Moringa oleifera leaves. J Toxicol. 2014:1-13.

19. Cerf CE. Beta cell dysfunction and insulin resistance. Front Endocrinol (Lausanne). 2013;4:37.

20. Kaneto H, Kajimoto Y, Miyagawa J, et al. Beneficial effects of antioxidants in diabetes: possible protection of pancreatic $\beta$-cells against glucose toxicity. Diabetes. 1999;48(12):2398-2406.

21. Prentki M, Nolan CJ. Islet $\boldsymbol{\beta}$ cell failure in type 2 diabetes. $J$ Clin Invest. 2006;116(7):1802-1812.

22. Kamalakkannan N, Prince PS. Antihyperglycaemic and antioxidant effect of rutin, a polyphenolic flavonoid, in streptozotocin-induced diabetic wistar rats. Basic Clin Pharmacol Toxicol. 2006;98(1):97-103.

23. Al Malki AL, El Rabey HA. The antidiabetic effect of low doses of Moringa oleifera Lam. seeds on streptozotocin induced diabetes and diabetic nephropathy in male rats. Biomed Res Int. 2015:1-13.

24. Aronson D, Rayfield RA. How hyperglycemia promotes atherosclerosis: molecular mechanisms. Cardiovasc Diabetol. 2002;1:1.

25. Chumark P, Khunawat P, Sanvarinda Y, et al. The in vitro and ex vivo antioxidant properties, hypolipidaemic and antiatherosclerotic activities of water extract of Moringa oleifera Lam. Leaves. J Ethnopharmacol. 2008;116(3):439-446.

26. Tiloke C, Phulukdaree A, Chuturgoon AA. The antiproliferative effect of Moringa oleifera crude aqueous leaf extract on cancerous human alveolar epithelial cells. BMC Complement Altern Med. 2013;13:226233 .

27. Jung IL. Soluble extract from Moringa oleifera leaves with a new anticancer activity. PLOS ONE. 2014;9(4):1-10.

28. Leelawat S, Leelawat L. Moringa olefiera extracts induce cholangiocarcinoma cell apoptosis by induction of reactive oxygen species production. Int J Pharmacogn Phytochem Res. 2014;6(2):183-189.

29. Liou GY, Storz P. Reactive oxygen species in cancer. Free Radic Res. 2010;44(5):479-496.

30. Hermawan, Nur KA, Sarmoko, et al. Ethanolic extract of Moringa oleifera increased cytotoxic effect of doxorubicin on HeLa cancer cells. J Nat Remedies. 2012;12(2):108-114.

31. Fahey J, Muna Abdalla I. Moringa oleifera: a review of the medical evidence for its nutritional, therapeutic, and prophylactic properties. Trees Life J. 2005;1:1-33.

32. Miyoshi N, Uchida K, Osawa T, et al. A link between benzyl isothiocyanate-induced cell cycle arrest and apoptosis: involvement of mitogen-activated protein kinases in the Bcl-2 phosphorylation. Cancer Res. 2004;64(6):2134-2142.
33. Lee YJ, Shacter E. Oxidative stress inhibits apoptosis in human lymphoma cells. J Biol Chem. 1999;274(28):19792-19798.

34. Baker K, Marcus CB, Huffman K, et al. Synthetic combined superoxide dismutase/catalase mimetics are protective as a delayed treatment in a rat stroke model: a key role for reactive oxygen species in ischemic brain injury. J Pharmacol Exp Ther.1998;284(1):215-221.

35. Kirisattayakul W, Wattanathorn J, Tong Un T, et al. Cerebroprotective effect of Moringa oleifera against focal ischemic stroke induced by middle cerebral artery occlusion. Oxid Med Cell Longev. 2013:10-13.

36. Sutalangka C, Wattanathorn J, Muchimapura S, et al. Moringa oleifera mitigates memory impairment and neurodegeneration in animal model of age-related dementia. Oxid Med Cell Longev. 2013:1-9.

37. Adeyemi OS, Elebiyo TC. Moringa oleifera supplemented diets prevented nickel-induced nephrotoxicity in Wistar rats. J Nutr Metab. 2014:1-8.

38. Ravikumar K, Sheeja AK. Heavy metal removal from water using Moringa oleifera seed coagulant and double filtration. Int J Sci Eng Res. 2013;4(5):10-13.

39. Mahajan GS, Mehta AA. Anti-arthritic activity of hydroalcoholic extract of flowers of Moringa oleifera lam. in Wistar rats. J Herbs Spices Med Plants. 2009;15(2):149-163.

40. Chen M, Verdes RP. Elucidation of bactericidal effects incurred by Moringa oleifera and Chitosan. J US SJWP. 2009;4:65-79.

41. Viera GHF, Mourão JA, Ângelo AM, et al. Antibacterial effect in vitro of Moringa oleifera and Annona muricata against Gram positive and Gram negative bacteria. Rev Ins Med Trop Sao Paulo. 2010;52(3):129132.

42. Jahn SA, Musnad HA, Burgstaller $H$. The tree that purifies water: cultivating multipurpose Moringaceae in the Sudan Unasylva. 1986;38:23-28.

43. Choudhary MK, Bodakhe SH, Gupta SK. Assessment of the antiulcer potential of Moringa oleifera root-bark extract in rats. J Acupunct Meridian Stud. 2013;6(4):214-220.

44. Nair S, Varalakshmi KN. Anticancer, cytotoxic potential of Moringa oleifera extracts on HeLa cell line. J Nat Pharm. 2011;2:138-142

45. Monera TG, Maponga CC. Prevalence and patterns of Moringa oleifera use among HIV positive patients in Zimbabwe: a cross-sectional survey. J Public Health Afr. 2012;3(1):6-8.

46. Lalas S, Tsaknis J. Characterization of Moringa oleifera seed oil variety Periyakulam-1. J Food Compos Anal. 2002;15(1):65-77.

47. Lurling M, Beekman W. Anticyanobacterial activity of Moringa oleifera seeds. J Appl Phycol. 2010;22(4):503-510.

48. Sengupta ME, Keraita B, Olsen A, et al. Use of Moringa oleifera seed extracts to reduce helminth egg numbers and turbidity in irrigation water. Water Res. 2012;46(11):3646-3656.

49. Suhartini S, Hidayat N, Rosaliana E. Influence of powdered Moringa oleifera seeds and natural filter media on the characteristics of tapioca starch wastewater. Int J Recycl Org Waste Agric. 2013;2:1-11.

50. Santos TR, Silva MF, Nishi L, et al. Development of a magnetic coagulant based on Moringa oleifera seed extract for water treatment. Environ Sci Pollut Res. 2016:23(8):7692-700.

51. Adejumo OE, Kolapo AL, Folarin AO. Moringa oleifera Lam. Moringaceae grown in Nigeria: in vitro antisickling activity on deoxygenated erythrocyte cells. J Pharm Bioall Sci. 2012;4(2):118-122.

52. Shank LP, Riyathong T, Lee VS, et al. Peroxidase activity in native and callus culture of Moringa oleifera Lam. J Med Bioeng. 2013;2(3):163167. 
53. Fuglie LJ. The Moringa Tree: A local solution to malnutrition; Church World Service in Senegal: 2005

54. Aluko O, Brai MR, Adelore AO. Materials evaluation of sensory attributes of snack from maize-moringa seed flour blends. Int J Innov Res Sci Eng Technol. 2013;7:597-599.

55. Owusu D, Oduro I. Development of crackers from cassava and sweetpotato flours using Moringa oleiferaand Ipomoea batatas leaves as fortificant. Am J Food Nutr. 2011;1(3):114-122.
56. Raphaël KJ. Effects of substituting soybean with Moringa oleifera meal in diets on laying and eggs quality characteristics of KABIR chickens. $J$ Anim Nutr. 2015;1(4):1-6.

57. Olugbemi TS, Mutayoba SK, Lekule FP. Effect of Moringa M. oleifera inclusion in cassava based diets fed to broiler chickens. Int J Poult Sci. 2010;9(4):363-367. 